\title{
Analyzing Urban Sprawl and Sustainable Development in Dhaka, Bangladesh
}

\author{
Lei Wang Provash Kumer Sarker* \\ School of Economics and Management, PO BOX: 430072; Villa No.5, Institute for the Development of Central \\ China, Wuhan University, P.R.C.
}

\begin{abstract}
The paper examines the impact of urban sprawl on sustainable development in Dhaka megacity, applying a comprehensive analysis. The study selected the greater Dhaka region as the study area. Besides quantitative analysis, the paper also used the widely accepted definition of sprawl to confirm the existence of sprawl in the context of Dhaka. It also employed the Pairwise Ranking Matrix (PRM) to determine the most contributing factors of urban sprawl in Dhaka. The ArcGIS and Remote Sensing tools were used to investigate and indicate urban sprawl patterns and land-use change from 1990 to 2017. The findings confirmed that Dhaka was slowly experiencing processes of urban sprawl, particularly in Southern, Western, and Eastern local regions. As policy tools, this paper contributed to the designing of effective spatial planning and strategies for planned urban growth and sustainable development.
\end{abstract}

Keywords: Urban sprawl; Sustainable development; Dhaka; Spatial planning; ArcGIS

DOI: $10.7176 / \mathrm{JESD} / 11-6-02$

Publication date:March $31^{\text {st }} 2020$

\subsection{Introduction}

Urban sprawl is a particular kind of unplanned urban growth with numerous adverse effects. This paper considered the definition of sprawl under the functional relationships between land use and users. (Jaeger, 2010) proposed that urban sprawl is a phenomenon perceived in the landscape. Other authors (Burgess \& Thomas, 1998) defined sprawl as expanding physical development, at decreasing densities, in metropolitan regions, where the spatial growth exceeds population growth. A definition considering all essential components of urban sprawl taken to analyze urban sprawl in the Greater Dhaka Region (hereafter referred to Dhaka megacity) is a market-driven force, random process of inefficient spatial expansion of urban, peri-urban areas into the surrounding rural or natural lands. Thus, monitoring, analyzing, and modeling of this phenomenon seem to be very crucial for Dhaka megacity. Megacities are defined as highly dynamic urban systems having over 10 million inhabitants (Pelling \& Blackburn, 2013). In recent times, all developed and developing countries are experiencing sprawl because of the rapidly increasing population, migration, and economic development. Today, $55 \%$ of the world's population lives in urban areas, a proportion that is expected to grow to $68 \%$ by 2050 (UN, 2018). In 2018 , an estimated $55.3 \& \%$ of the world's population lived in urban settlements. Identically, by 2030, urban areas are projected to house $60 \%$ of people globally, and one in every three people will live in cities with at least half a million inhabitants (The World Cities, 2018). We see this when rapid population growth has led people to migrate from rural areas to cities for better living. Thus, by causing a constant influx of rural people to cities and towns, urban migration increases the density. For Dhaka, the fast increase in population, induced urban migration, and density paints the same picture making it the third densely populated city in the world (www.worldatlas.com, 2018). As hyperdensity affects every aspect of the living state, it has become crucial to examine and control the ongoing sprawling process in Dhaka megacity to make the future of the city sustainable. In line with this, the paper is set to explore emerging and interrelated urban sprawl factors, the land-use change, and urban growth patterns and the risk associated with it in the Dhaka megacity. It also recommends a sustainable development pathway for the growth of this emerging city. To identify the urban sprawl, the paper examined three primary objectives; (1) to identify the most significant urban sprawl factors in Dhaka using the Pairwise Ranking Matrix; (2) to assess urban sprawl pattern of the study area using ArcGIS and Remote Sensing Approach; and (3) to explore potential planning policies for sustainable development of Dhaka.

\subsection{Background}

This paper surveyed the recent literature to review the fastest-growing megacities of the developing world by investigating the urban sprawl process and various socio-economic as well as ecological impacts. However, in recent literature, there are few comprehensive studies on urban sprawl in megacities to the best of our knowledge. Moreover, the recent studies may not have examined the spatial expansion patterns induced by informal urbanization and vulnerabilities from environmental degradation, which motivated the authors to work further about the urbanization process and vulnerabilities. In doing so, this paper studied the connection between the challenges posed by population explosion, urbanization, and climate change impacts. Upon reviewing the recent literature, authors found that developing countries often struggle with the management, planning, and governance 
of the megacities, and result in "unmanaged urbanization creating massive urban infrastructure backlogs, haphazard urban sprawl, and compound environmental problems" (Kabir, 2013). Other authors mentioned that with hyper-population growth, Dhaka is struggling to ensure the quality of its urban life and sustainable growth, including infrastructure, water supply, sanitation, and housing (Degert, Parikh, \& Kabir, 2016); (Onodera, 2013) . However, the concept of informal urbanization appeared in the literature to define the growth of informal settlements inhabited by the urban poor (Hackenbroch, Hossain, Altrock, Schoon, \& Sterly, 2016). In addition to the growing population, an informal economy in the form of street-based self-business, home-based works, and construction labor employs a significant number of people in megacities in parallel with formal job sectors (Daniels, 2004).

In more recent literature, researchers argue that urban elites exercise power through socio-political networks for land grabbing and manipulating planning decisions for personal benefits. Thus, random and illegal housing development has become a common scenario in the urbanization of megacities. In effect, "large urban agglomerations are expanding and densifying rapidly with only marginal and sporadic planning regulation" (Baumgart \& Kreibich, 2011). Urban scientists and economists suggest that megacities may be at increased risks of unplanned urbanization, social disparity, and uncoordinated urban governance systems. With this added dimension of urban challenges, growth dynamics and management perspectives have become more complicated. The Dhaka city is now facing informal urbanization attributed by constant population growth, urban migration, and booming industrialization.

\subsection{Main focus of the paper}

Dhaka megacity accommodates around 19.58 million people, and this figure is expected to reach 28 million by 2030. Besides, about $63 \%$ of the total population growth in Dhaka is attributed to in-migration, and the remaining growth is due to natural increase (RAJUK, 2015). The density is higher, mainly in the core region of the city (DNCC and DSCC) ${ }^{1}$ area, which has alarmingly increased from 34,635 per km² in 2001 to 49,182 per km² in 2018. Thus, it made Dhaka an overcrowded and uninhabitable living environment (Corner \& Dewan, 2014).

In this perspective, it is worth mentioning that Dhaka is experiencing urban sprawl due to uncontrolled urban migration, population growth, random housing projects, unplanned setting-ups of medium-scale manufacturing industries, warehouses, and lower-income residences. For example, by single land-use change indicators throughout 2000 to 2010, Dhaka district lost some 2.5 hectares of fertile land every day due to unplanned brick kiln set-ups, random housing projects, increased industrial structures as well as roads and infrastructure builts-ups. In Savar, the agricultural land shrunk from 18,634 hectares to 17,580 hectares from 2000 to 2010 period for unplanned brick kilns, manufacturing, and other industries set-ups. Keraniganj comprises 16,997 hectares of land, and its agricultural land has reduced to 9,688 hectares from 11,380 hectares due to random real estate development. This loss of agricultural land forced about 300,000 farmers of the district to change their professions and to migrate to cities. As the urban sector in Bangladesh is the main thrust of the economy, which contributes more than $60 \%$ of the GDP (Choe \& Roberts, 2011), rural people come to the city for better living and livelihood. The city offers $43.6 \%$ of the total formal employment in the country consisting of office jobs, business, and manufacturing industries (RAJUK, 2015). Dhaka provides a large scale of informal employment, including rickshaw operation, hauling, street vending, and household services run by the urban poor. Gradually, the majority of the agricultural lands and wetlands were transformed into hasty and haphazard built-up areas to accommodate the growing population. This random spatial expansion of Dhaka took a new turn in urbanization with multiple impacts on urban life. However, to manage the city well, the Local Government Amendment Act (2011) divided Dhaka City Corporation into Dhaka North City Corporations and Dhaka South City Corporation in 2011 for subdividing the management works (DSCC, 2012). These two city corporations are responsible for providing and managing municipal services, solid waste management, community development, and health-related projects. The authors will define urban sprawl of Dhaka megacity in the next paragraph.

The rest of the paper is organized as follows. Section two states the methodological set-up of the study. Section three interprets the results of the analyses of urban sprawl and factors causing it regarding Dhaka. Section four discusses the impacts of urban sprawl, while section five recommends the policy tools for sustainable development in megacities. Section six concludes the study.

\subsection{Data and Methods}

The study was prepared based on both primary and secondary data. Primary data were collected through a classbased group discussion to identify the most dominant sprawl factors in Dhaka in order of priority using the Pairwise Ranking Matrix (PRM). To get secondary data, the authors viewed and considered various organizations, journals, research papers, working papers, conference papers, and newspapers. This study downloaded cloud-free Landsat 8 TM images from Glovis for the years; 1990, 1995, 2000, 2005, 2010, 2015, and 2017 to get the spatial data about

\footnotetext{
${ }^{1}$ DNCC and DSCC refer to Dhaka North City Corporation and Dhaka South City Corporation respectively which are core city regions.
} 
built-up area expansion in the Dhaka megacity. The paper also used a built-up area density indicator, urban population density indicator, physiological density indicator, openness index, proximity index, and cohesion index to measure urban sprawl. Finally, Google Earth Landsat 8 TM imageries of the past 27 years (1990-2017) were used by ArcGIS 10.6 tools to analyze the land-use change patterns in Dhaka for achieving research objectives.

\subsection{Results and Analysis}

To curb urban sprawl, we first need to measure it effectively to understand better how and where it has occurred (Burchfield M., 2006). Similarly, to better identify and assess the existence of sprawl in Dhaka, the paper used the urban population density, built-up area density, physiological density, and land-use change (1990-2017). The following sections will analyze and illustrate the results.

\subsection{Population density and built-up area density}

Population density is the total number of populations to its land area. It is expressed as the total number of populations to its total land areas (Black, 1996; Alberti, 1991; Burchell, 2005). Sprawl exists in low-density real estate development, which is the geometric use of land for urban purposes along the margins of existing Dhaka metropolitan areas. This study adopted the primary zoning of Dhaka from the (DMDP, 2007). The paper has divided the Dhaka megacity into three major zones ${ }^{1}$ based on infrastructural development and economic activities to understand spatial growth better. This three-zone trisect provided a more specific overview of population and built-up density to investigate better and monitor the urban growth pattern in Dhaka.

Table 1. Population Density per $\mathrm{km}^{2}$ and Built-up (BU) area density per hectare ${ }^{2}$ in 3 Major Zones of Dhaka

\begin{tabular}{|c|c|c|c|c|c|c|c|c|c|}
\hline & \multicolumn{4}{|c|}{ Dhaka City } & \multicolumn{3}{c|}{ Gazipur, Savar, Narayanganj } & \multicolumn{2}{c|}{ Keraniganj, Bandar, Sonargaon, Rupganj } \\
\hline Year & Density & BU Density & BU (ha) & Density & BU Density & BU (ha) & Density & BU Density & BU (ha) \\
\hline 1990 & 14,950 & 404 & 6,882 & 3,204 & 629 & 1,578 & 2,759 & 5262 & 541 \\
\hline 1995 & 20,159 & 455 & 8,244 & 4,301 & 360 & 3,695 & 3,149 & 4779 & 680 \\
\hline 2000 & 26,542 & 497 & 9,931 & 5,972 & 395 & 4,678 & 3,388 & 2492 & 1403 \\
\hline 2005 & 33,148 & 525 & 11,738 & 7,558 & 368 & 6,355 & 3,704 & 2433 & 1571 \\
\hline 2010 & 41,182 & 606 & 12,637 & 9,028 & 222 & 12,564 & 4,139 & 1941 & 2201 \\
\hline 2015 & 50,142 & 642 & 14,523 & 11,921 & 210 & 17,591 & 4,433 & 814 & 5623 \\
\hline 2017 & 51,954 & 645 & 14,985 & 13,188 & 211 & 19,335 & 4,682 & 676 & 7151 \\
\hline
\end{tabular}

Source: (1). Dhaka Metropolitan Development Plan Strategic Environment Assessment Report, 2007; (2). Authors' estimates on population density in each zone based on World Urbanization Prospects -United Nations population estimates and projections of major Urban Agglomerations; (3) Bangladesh Bureau of Statistics - Dhaka information and statistics.

Table 1 shows population density in the old Dhaka city was the highest over the periods and became a severe problem for city dwellers. The core area spatially remains the same $\left(186 \mathrm{~km}^{2}\right)$ while the number of populations grew hurriedly. This rapid increase in population can be explained by the hyper-concentration of all economic, business, and administrative activities in the core of the city, which caused an influx of enormous population resulting in high density. Both DNCC and DSCC were developing the undeveloped land mainly for the growing demand for housing and municipal services. Besides, we found the most recent infrastructural development includes the extension of built-up areas in Banani, Gulshan, Baridhara area, Kawranbazar, Mohakhali and Postogola commercial area, Sonargaon hotel area, Motijheel commercial area, Uttara model town, Hatirjheel project, Jhilmil project, Adabor housing project, Mohammadpur housing, Janata Housing in Mirpur-1, road network from Kalshi to Uttara, Mohammadpur to Bochila, Beribadh, Raier bazaar and many were made due to accommodate and facilitate the additional population. The findings confirmed that as this spatial expansion was planned and increasing density trend, there was no sprawl in core city areas.

Built-up area density from 1990 to 2017 in developing regions (Gazipur, Narayanganj, Savar) was significantly increased. It meant that infrastructural development was taking place for the industry, and scattered residential development was happening in the peri-urban areas. A decrease in population density while built-up land was increasing, meaning that there was sprawl. The same scenario held in the case of fringe areas (Sonargaon, Bandar, Rupganj, Keraniganj). Residential built-up was also increasing in the same axis but at a slow pace and alongside the highways or commuting roads and railways. Geographic expansion in that landscape way (i.e., sprawl) results in inefficient use of land, low density, loss of arable lands, and ecological degradation. The analyses of the paper may contribute to policy calibration for the concerned authorities regarding managing the spillover effect of sprawl on the environment and economic resources in Dhaka.

\footnotetext{
${ }^{1}$ Developed Area: Old Dhaka city area covering about $186.12 \mathrm{~km}^{2}$.

Developing Areas: Extended areas in the DCC (part of the 6 Thanas: Demra, Sabujbagh, Uttara, Kamrangirchar, Badda, Shyampur) and Paurashavas (Naraynganj, Kadamrasul, Savar, Tongi and Gazipur) covering an area $309.96 \mathrm{~km}^{2}$.

Fringe Area: Rural Areas under Union Parishad (part of Demra Thana, Sabujganj Thana, Uttara Thana, Badda Thana, Shyampur Thana, Kamrangircahr Thana, Savar Upazila, Keraniganj Upazila, Gazipur Sadar Upazila, Rupganj Upazila, Bandar Upazila and Narayanganj Sadar Upazila) covering an area $1032.96 \mathrm{~km}^{2}$.
} 
Table 2. Built-up area statistics (ha) in Greater Dhaka by regions

\begin{tabular}{|c|c|c|c|c|c|c|c|}
\hline Built-up & $\mathbf{1 9 9 0}$ & $\mathbf{1 9 9 5}$ & $\mathbf{2 0 0 0}$ & $\mathbf{2 0 0 5}$ & $\mathbf{2 0 1 0}$ & $\mathbf{2 0 1 5}$ & $\mathbf{2 0 1 7}$ \\
\hline Dhaka City* & 6,882 & 8,244 & 9,931 & 11,738 & 12,637 & 14,523 & 14,985 \\
\hline Gazipur & 818 & 1,434 & 1,684 & 2,277 & 4,554 & 7,640 & 8,754 \\
\hline Savar & 148 & 628 & 1,274 & 1,861 & 4,660 & 5,071 & 5,860 \\
\hline Narayanganj & 612 & 1,633 & 1,720 & 2,217 & 3,350 & 4,880 & 5,321 \\
\hline Keraniganj & 296 & 338 & 539 & 557 & 629 & 1,952 & 2,467 \\
\hline Bandar & 152 & 196 & 482 & 579 & 667 & 1,532 & 1,923 \\
\hline Rupganj & 53 & 76 & 197 & 231 & 627 & 1,288 & 1,766 \\
\hline Sonargaon & 40 & 70 & 185 & 204 & 278 & 851 & 995 \\
\hline
\end{tabular}

Source: The built-up area statistics are derived from generated land cover maps of Dhaka megacity

This study shows the spatial distribution of built-up areas in the developed city (Dhaka city), developing cities (Gazipur, Savar, and Narayanganj) and fringe areas (Keraniganj, Bandar, Rupganj, Sonargaon).

Gazipur: Due to the availability of low-cost land with proximity to the core city area, Gazipur became the primary target of both residential and industrial development in recent times. As a result of arable land conversion into the built-up area, the built-up growth rate in Gazipur is substantially higher than any other urban center studied in this paper. The top urban growth in the region was recorded in the 2005-2015 periods at the rate of $100 \%$ and $68 \%$, respectively. This growth was due to both industrial expansion and population migration in the region. However, the population density decreased (691 to 211 per hectare) with an increase of built-up areas, which meant few people were covering scattered areas using agricultural lands. Such a phenomenon was an inefficient use of land and an economic loss of resources. On the other hand, it was an adverse effect on the spatial environment.

Savar: Table 2 shows that the trend of urban growth in Savar continued in the subsequent years from 1990. For instance, in the period between 1990 and 1995, the total urban growth in Saver was approximately 325\%, with an annual increase rate of $34 \%$. The total built-up area reached 4,660 hectares in 2010. The built-up area in Savar took away agricultural lands due to low-income housing projects, roads, and lanes and commercial set-ups for growing manufacturing, ceramic, weaving, dairy, foods, and garments industries. The outright effect of the sprawl was unconnected traffic service for commuters, deforestation, random filling-ups of wetlands causing environmental hazards economic loss of resources.

Narayanganj: In recent times, the city was expanding towards the northwest, following the old line of the Dhaka-Narayanganj highway. As a result, a large area experienced rapid and chaotic urban development resulted in a fast land conversion from agricultural-lowland to residential development. The built-up area, therefore, increased from 612 hectares in 1990 to 1,720 hectares in 2000 , a growth rate of $181 \%$. The developed land in Narayanganj is expanding much faster in recent times due to the establishment of several planned industrial estates in Enayetnogor, Fatulla, Adamji, Kanchpur, and Panchabati, which are the most massive urban clusters in the region. Thus, sprawl-induced by industrial expansion resulted in environmental degradation due to the loss of green and open space.

Keraniganj: Table 2 shows that the built-up area in 1990 was approximately 296 hectares in Keraniganj. However, these areas underwent rapid urbanization in recent times due to several connecting bridges over Buriganga. The significant urban development in Keraniganj is observed in Zinzira, Ragunathpur, Mandail, Kalindi, Barisur, Bamonsur, Dakpara, Kaliganj, and towards Mirerbag. Besides, the area houses many small and medium-scale manufacturing industries, warehouses, and lower-income residences. The ongoing massive-scale residential development projects in Ekuria were making this area urbanize rapidly. As shown in from 1990 to 2017 (Table 2), the total built-up area in Keraniganj increased by $733 \%$. The increase in the built-up area was mainly due to medium to low-income housing projects and traffic infrastructure.

Bandar: Bandar showed a fast land cover change in recent years. The built-up area increased from 152 hectares in 1990 to 1,923 hectares in 2017 , with a growth rate of $1,163 \%$. The highest increase was observed between 1995 and 2000 when the total built-up growth was 137\% (Table 2). Within this conversion to built-up land, the most substantial portion was industrial and port-related infrastructure development, like a ship breaking industry infrastructure and associated transport development.

Among the connecting urban growth centers (Sonargaon, Rupganj, and Kaliganj) in this study, the increasing built-up area was recorded in Soanargaon and Rupganj. This increase implies pressing policy concerns regarding how and where this spatial expansion was taking place and measures to control it. Consequently, this paper pointed out the factors causing urban sprawl with rigorous data.

\subsection{Index analysis of Dhaka city}

From 1991 to 2014, due to the rapid increase in population and the built-up area, the openness index decreased. It captured the real picture in Dhaka city that the additional built-up areas were consuming more open spaces like roads, parks, playgrounds, and as such (figure 1). 


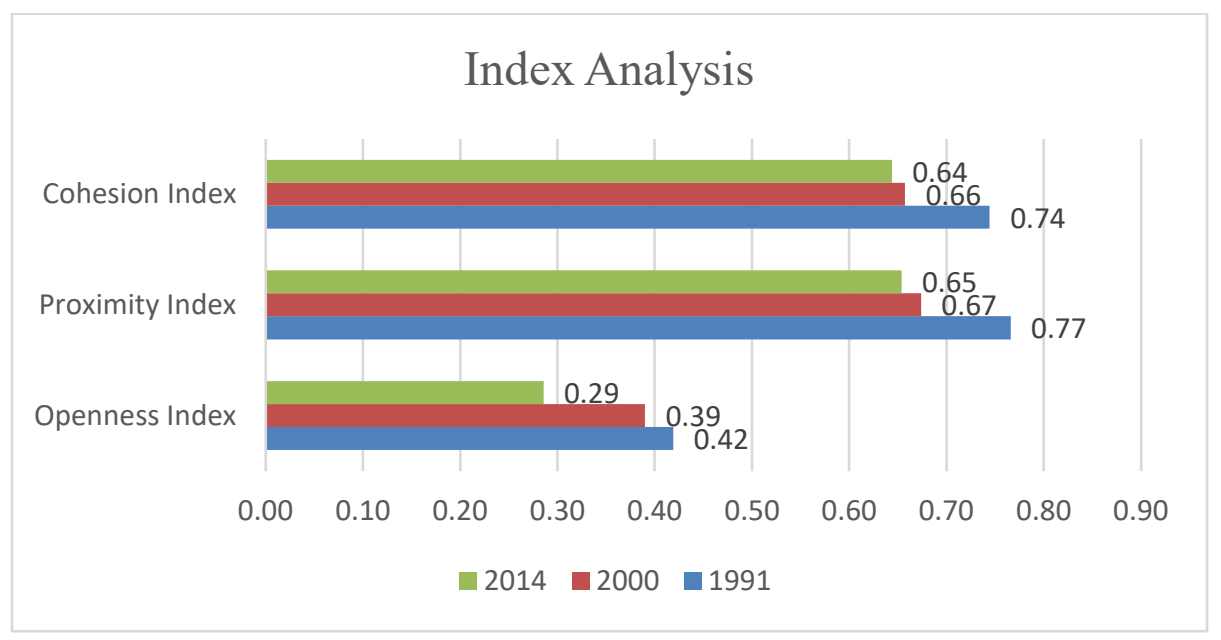

Figure 1. Openness, Proximity and Cohesion Index Analysis

Figure 1 shows that the openness index decreased from 0.42 to 0.29 . This 0.13 decrease in openness index happened due to the spatial extension of the core area in city corporations. For example, in the Dhaka metropolitan area, Tejgaon lost about 2,500 hectares of agricultural land.

In comparison, Mohammadpur and Gulshan lost about 300 hectares and 500 hectares, respectively, due to unplanned and random housing for the migrated and added population. This loss resulted in growing up built-up areas meaning the decrease in open space such as no park, no greeneries, lakes, ponds, and playgrounds. The same happens to proximity and cohesion indices as well. The index value of proximity and cohesion decreased by 0.12 and 0.10 , which meant a policy scope for the policymakers, mayors, and other administrative authorities. Fall in proximity and cohesion implies that built-up areas were developed dispersedly covering many kilometers with few buildings. Neo-urban areas had low proximity to built-ups, which means that the urbanization process was approaching nearby fringe areas. These findings support the findings of land-use change maps (figure 1). From 1991 to 2014, the proximity index fell ten basis points. Both cohesion and proximity indexes in the case of Gazipur, Savar, and Narayanganj followed almost the decreasing pattern over the same period. Thus, it indicated that there was unplanned urban growth in this megacity. The index analysis of this paper can effectively help to formulate the specific policies based on the sustainability aspect of the city.

\subsection{Land-use change in Dhaka megacity}

A land-use change indicator is a useful tool for analyzing urban land development. Likewise, sprawled land-use patterns increase the amount of land developed per capita, which reduce the area left as green space (biologically productive land such as farms, forest, and wetlands near urban centers. (Kusher, 2001) mentioned that using a land-use activity at rural land to define sprawl as the spreading out of a city and its suburbs over more and more rural land at the periphery of an urban area involves the conversion of open space (rural land) into built-up and developed land over time. 

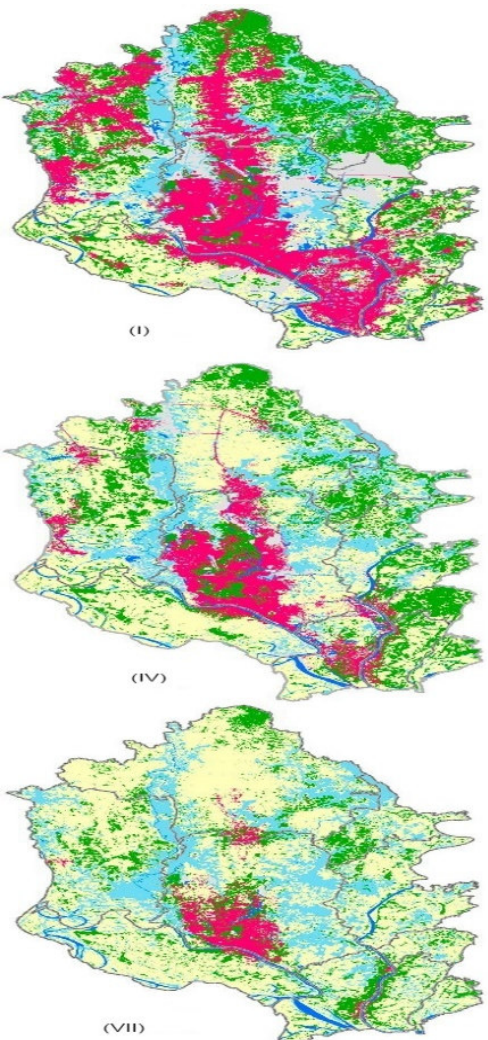
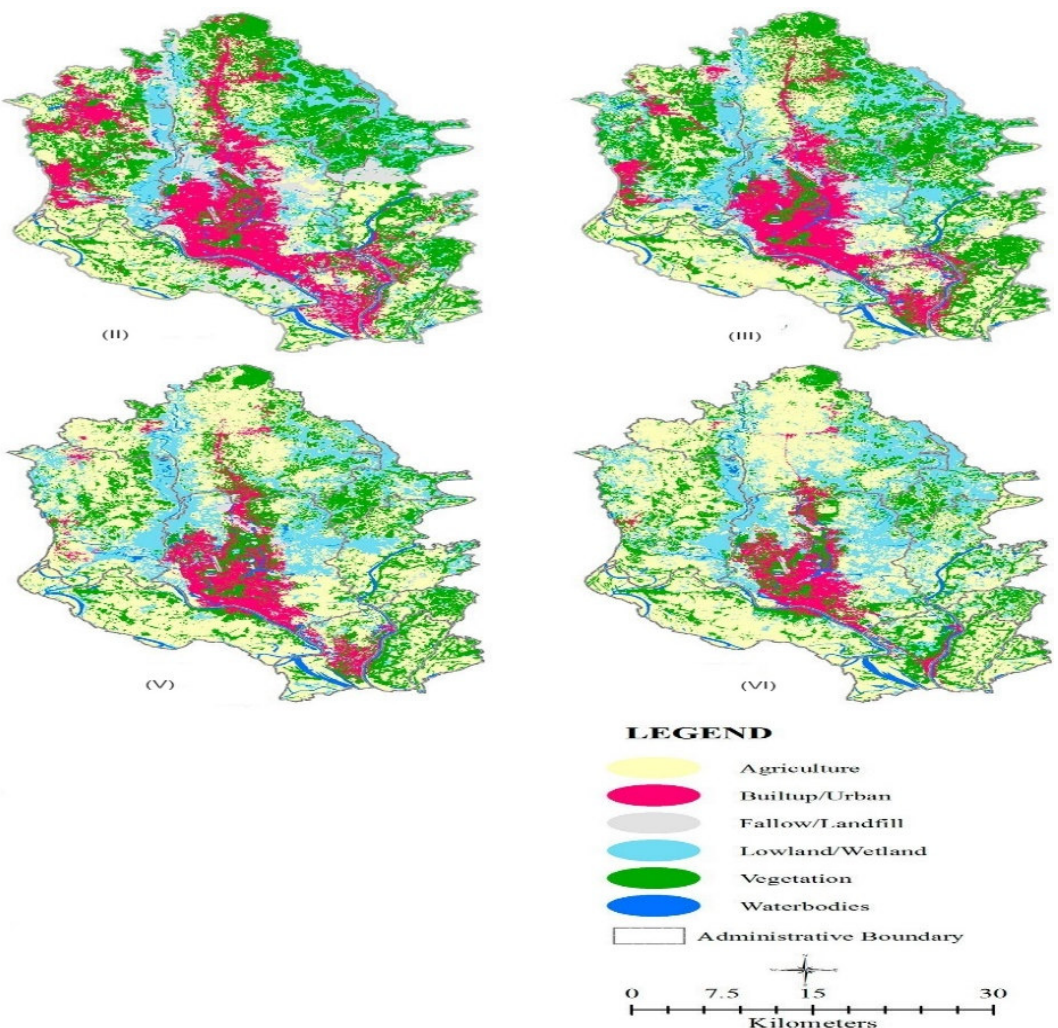

Figure 2. Land cover maps in greater Dhaka from1990 to 2017: (I) 2017; (II) 2015; (III) 2010; (IV) 2005; (V) 2000; (VI) 1995; (VII) 1990

The above map is generated from Landsat Images (1990-2017) using ArcGIS 10.6. The spatial pattern of urban expansion between 1990 and 2017 shows that Dhaka and its surrounding areas experienced rapid urbanization, which resulted in significant changes in land use over the 27 years studied. The spatial trajectory of urban expansion over the study period shows that north, northwest, and southeast were the major directions experiencing urban development. By contrast, southern and western expansion is relatively low since the southern and western zones are mainly low-lying marshy land, impeding the growth of built-up areas in these directions. The urban growth was estimated from the map over the 27 years in the direction toward the north ( $35 \%$ expansion), along the Dhaka-Mymensingh highway (Tongi-Gazipur) and northwest (30\% expansion), the Savar-Ashulia corridor along the Dhaka-Aricha highway, and also toward the southwest (25.6\%) along the Dhaka-Narayanganj, and Dhaka-Chittagong highways. The development towards the north was significant due to comparatively floodfree land in that direction and particularly several development projects, such as shifting the airport from its old site at Tejgaon to its new site north of Kurmitola, which is about $10 \mathrm{~km}$ north of the old airport. North of Uttara stands the industrial town of Tongi. Due to population growth and the subsequent expansion of trade and commerce, the current development of the city is expanding its radius to southwest, north, northeast, west, and northwest from the banks of the Buriganga River and extending into rural areas and beyond the outskirts. This change took place significantly after 2010 (figure 2).

Further findings show that the proximity of residential buildings is not continuous in forms but scattered. Northeast of Gazipur, and Tongi, most of the built-up areas are discontinuous and dispersed. The development alongside the Dhaka-Gazipur highway is locational; near the industrial areas, built-ups are compact, but after 2-3 $\mathrm{km}$ far away, the continuity ceases resulting in sprawl. The same happens to Narayanganj as well. Built-up area $(62 \%)$ in Fatulla, Panchoboti, Chasara, Rupganj, Sonargaon, Bandar, and Siddhirganj is continuous in the garment, textile, cottage, cotton, weaving, yarn and dyeing shipyard, and brickfield industries in nearby areas. Savar hosts many manufacturing facilities, including ceramic industry, garments industry, footwear, jute \& textile mills, automobile industry, pharmaceutical industry, soap factory, brickfield, cottage industry, and Export Processing Zones which provided substantial employment opportunities. In Savar, almost $70 \%$ of the built-up areas are concentrated in industry peripheral areas leaving inefficient use and loss of arable land in those territories. In the years between 2010 to 2017, the lands use changes occurred in Gazipur and Savar horizontally fast while in Narayanganj, the spatial expansion occurred in relatively bit far distant places from city proper. Kaliganj in the northeast of this study area is a predominantly agricultural, rural, and peri-urban settlement ( $53 \%$ in total). The land use survey of 2006 estimates that $23 \%$ of the entire land of Tongi, Gazipur, Kaliganj, and Rupganj was residential, including urban housing, rural homesteads, and informal housing; less than $1 \%$ is designated for 
industrial and commercial uses, and $60 \%$ land is used for agricultural purposes. By land-use change, this expansion occurred at the cost of arable lands and environmental loss. However, with proper spatial planning and zoning, regional planners can easily manage such sprawling events.

\subsection{The physiological density of Dhaka}

This measure of population density refers to the number of populations per unit area (hectare in this paper) of arable land, an essential indicator of a country's food-producing capability, and the human pressures placed upon it. A higher physiological density suggests that the available agricultural land is being used by more and may reach its output limit. Table 3 shows the physiological density changes over a certain period in the Dhaka city, Savar, Narayanganj, and Gazipur areas.

Table 3. Physiological density per hectare of arable land in DCC, Savar, Narayanganj, and Gazipur.

\begin{tabular}{|c|c|c|c|c|c|c|}
\hline \multicolumn{1}{|c|}{ Year } & $\mathbf{2 0 0 0}$ & $\mathbf{2 0 0 5}$ & $\mathbf{2 0 1 0}$ & $\mathbf{2 0 1 5}$ & $\mathbf{2 0 1 7}$ & $\Delta \%$ \\
\hline DCC & 606 & 1,076 & 1,361 & 2,864 & 4,442 & $633 \%$ \\
\hline Savar, Narayanganj, Gazipur & 66 & 93 & 169 & 259 & 314 & $375 \%$ \\
\hline
\end{tabular}

Source: Author's work based on BBS report, 2013, 2015 and World Urbanization Prospects -United Nations population estimates and projections of major Urban Agglomerations, 2017

Table 3 shows that the physiological density both in DCC and developing areas (Savar, Narayanganj, and Gazipur) was substantially increasing, meaning that per capita arable land in terms of a hectare was decreasing. From 2000 to 2017, the physiological density rose to 4,442 per hectare in Dhaka city areas while 314 per hectare in the other three regions. The change in physiological density was around $633 \%$ and $375 \%$, respectively. Simple as it can be, the causes of this increase were population growth, urban migration, and rapid informal urbanization induced by industrialization. People were occupying more and more land for habitats and industrial establishments in Savar, Narayanganj, and Gazipur. More and more elevated land is necessary to accommodate these booming industries and populations. As a result, the only choice left was occupying arable land to build residential or industrial zones. Even the wetlands are found to be filled with sand for housing. However, if this situation continues, by 2050 , Dhaka will reach $90 \%$ usage of its arable land, reaching almost to its full capacity. It may have a severe impact on the ecology and sustainability of the city if not managed now in a planned way.

\subsection{Factors of the Urban Sprawl}

In the rapidly urbanizing Dhaka, identifying the driving factors that influence urban growth at different spatiotemporal scales is of considerable importance. The paper has analyzed and found out the significant factors causing sprawl in Dhaka.

The Most Dominant Urban Sprawl Factors: Dhaka Perspective

This research used the Pairwise Ranking Matrix (PRM) for analyzing and classifying a list of factors in priority order to identify the most dominant urban sprawl factors. This approach allows for creativity and discussion while maintaining quantifiable objectivity; this is achieved by utilizing a qualitative prioritization system that yields numerical values suitable for being compared and ranked (Harder, 2013).

Table 4. Pairwise Ranking Matrix $(\mathrm{PRM})^{1}$ to identify the most dominant urban sprawl factors in Dhaka, Bangladesh

\begin{tabular}{|c|c|c|c|c|c|c|c|c|c|c|c|}
\hline & & 1 & 2 & 3 & 4 & 5 & 6 & 7 & 8 & & \\
\hline & Factors & $\begin{array}{l}\text { Population } \\
\text { Growth }\end{array}$ & $\begin{array}{l}\text { Economic } \\
\text { Growth }\end{array}$ & Industrialization & $\begin{array}{l}\text { Urban in- } \\
\text { migration }\end{array}$ & \begin{tabular}{|l} 
Living and \\
property costs
\end{tabular} & $\begin{array}{c}\text { Lack of } \\
\text { affordable } \\
\text { housing }\end{array}$ & $\begin{array}{c}\text { Lack of proper } \\
\text { planning policies }\end{array}$ & \begin{tabular}{|l} 
Legal \\
Disputes
\end{tabular} & Score & Ranking \\
\hline 1 & Population Growth & & 1 & 1 & 1 & 1 & 1 & 1 & 1 & 7 & $\mathrm{l}^{\mathrm{t}}$ \\
\hline 2 & $\begin{array}{l}\text { Economic } \\
\text { Growth }\end{array}$ & 1 & & 2 & 2 & 5 & 6 & 2 & 2 & 4 & $4^{\text {th }}$ \\
\hline 3 & Industrialization & 1 & 2 & & 4 & 5 & 3 & 3 & 3 & 3 & $5^{\text {th }}$ \\
\hline 4 & Urban in-migration & 1 & 4 & 4 & & 4 & 4 & 4 & 4 & 6 & $2^{2 i}$ \\
\hline 5 & $\begin{array}{c}\text { Living and } \\
\text { property costs }\end{array}$ & 1 & 5 & 5 & 4 & & 5 & 5 & 5 & 5 & $3^{\text {ri }}$ \\
\hline 6 & $\begin{array}{l}\text { Lack of affordable } \\
\text { housing }\end{array}$ & 1 & 2 & 3 & 3 & 5 & & 6 & 6 & 2 & $6^{\text {th }}$ \\
\hline 7 & $\begin{array}{c}\text { Lack of proper } \\
\text { planning policies }\end{array}$ & 1 & 2 & 3 & 4 & 5 & 6 & & 7 & 1 & $7^{\text {th }}$ \\
\hline 8 & Legal Disputes & 1 & 2 & 3 & 4 & 5 & 6 & 8 & & 0 & $8^{\text {th }}$ \\
\hline
\end{tabular}

Source: Prepared by the authors, 2019 based on discussion among Ph.D. and graduate students at the School of Economics and Business, Wuhan University.

${ }^{1}$ This study has identified eight factors; 1 to 8 (high to low) is the degree of priority of one factor over others. The score is found by adding up the frequencies (tallying) of factors in their respective rows. For example, in row number 5 , we add the frequencies of 5 along the rows to get the score of factor five. The ranking is ordered from 1 to 8 is (high to low). 


\subsubsection{Population growth}

This paper aimed to find out the factors of urban sprawl in Dhaka. In line with that, it found the rapid growth of urban areas is the result of two population growth factors: (a) natural increase in population, (b) increase of urban in-migration. From 1990 to 2019, the total population increased from 6.62 million to around 20 million, which was almost $300 \%$ of 1990 in 19 years. By 2030, this city is expected to have around 25 million population. Ranked first in the matrix, this massive growth in the urban population may force to cause uncontrolled urban growth resulting in sprawl. The unchecked growth of cities strains the capacity to provide municipal utility services, for instance, electricity, gas, water, education, health care, transportation, sanitation, and physical security. Since the government has less revenue to spend on the necessary upkeep of cities and the provision of services, Dhaka has become areas of massive sprawl and serious environmental problems.

\subsubsection{Economic growth}

The economic growth rate in Bangladesh has risen from 5.622\% in 1990 to $7.63 \%$ in 2018. Over these 19 years, industrialization took place mostly in Gazipur, Savar, and Narayanganj. Paced with economic growth, the employment opportunity spotted at the built-up areas brought the rural people to cities and provided them with employment. For example, of the toral garments companies, $86 \%$ is concentrated in Gazipur and Savar alone. In contrast, the rest $14 \%$ is located in Mirpur, Banani, Uttara. In addition to EPZs, Dhaka also includes other trades and economic corridors. These commercial and industrial set-ups provide ample formal and informal employment opportunities that cause mobility of labor service. Rural young females, also male, migrate to Dhaka for the job and settle nearby towns. Accommodating such a rush of population encourages many developers for the rapid construction of new houses, buildings in the suburbs. This rapid development of housing and other urban infrastructure is producing a variety of discontinuous developments.

\subsubsection{Industrialization}

With the changes in the information, production, and transportation technologies, industrialization has changed a lot. To the extent that these changes substitute for geographic proximity, they have significantly increased the mobility of goods, services, labor, technology across the Dhaka. This paper found that from 1990 to 1995 , the built-up area in Gazipur, Savar, and Narayanganj grew 75\%, 324\%, and 166\%, respectively. Due to cheap labor and available land, the garment industry took place in Savar and Gazipur mostly. Since spatial economic activities significantly influence human habitation, the establishment of new industries in the suburban areas decreases farmland or green space rapidly. In Dhaka, almost all industries' (garments and manufacturing) factories and warehouses are established nearby regions to the metropolis. This industry settlement was due to cheap land. However, household people intending to provide labor service thrush to the industry spot and dwell nearby too. Thus, both human habitats and industry set-ups have increased the built-up areas in Dhaka city.

\subsubsection{Urban in-migration}

This study found that urban in-migration is ranked second and is the critical reason for urban sprawl in Dhaka. Every day, around 2,000 people move to Dhaka (McPherson, 2015). Bangladesh's capital city of 20 million people is growing by close to $5 \%$ a year, in part as rural families migrate to the city seeking work or have lost their homes (L. Goering, 2016). The PRM analysis showed that because of the garments manufacturing industry set-ups in Gazipur, Melamine, and Garment industry in; cotton and steel industry in Narayanganj, Chemical, and Tannery industries in Keraniganj, many rural people including females migrate to these localities to earn their living. Urban development and low-income housing pressure in Savar resulted from the establishment of several large-scale industrial zones, like the Dhaka Export Processing Zone in Dhamsona. As a result, the population swelled, due mainly to a significant influx of rural migrants looking for work in the booming industrial sectors in Savar. According to BBS, in 1991, some 33.2 persons in every 1,000 migrated to urban areas. The number increased to $67.3,69.7,68.1,77.1,90$ out of every 1,000 persons moved to urban areas in 2011, 2012, 2013, 2014, and 2015 respectively. Besides economic factors, a host of other factors like poverty, river erosions, natural disasters, along with marriages, healthcare and education are responsible for the soaring migration. However, migration to urban locality exerts pressure on housing and transport developments at the expense of agricultural lands.

Besides high living costs in the core city, lack of affordable housing, lack of contemporary planning \& policies, and legal disputes in ownership of land in Dhaka city also cause the population to move forward to the urban locality.

\subsection{Impacts of the Urban Sprawl}

Urbanization proceeds at a rapid pace in many parts of the globe and significantly affects the environment as well as the quality of life (Grimm, 2008) (Seto K., 2012). In Dhaka, the severe consequence of the excessive growth of the built-up areas, informal urbanization, has been the smothering of agricultural and sensitive lands. Coupled with that is the pollution and disappearance of water bodies and wetlands and the risk of flooding - other consequences such as increasing air pollution, rising expenditure on transportation, and rising car accidents. 


\subsection{Social impacts}

Urban sprawl changes the pattern of family relationships and individual behavior in Dhaka city. When residents move further out to suburban areas, they also have an impact on their social lives, commonly termed as social fragmentation. In urbanized areas, most families are single families. They do not have neighbors that live as close, which means that they will not stay as social as they should. Because of the uncoordinated urbanization and transport systems in Dhaka city, commuting people spend much time in public transports or cars (one-fourth of their working hours) and at homes at the weekend. People have little time or opportunity for social contact, gettogether, and frequent meetings along pedestrian-friendly streets and around public spaces. For instance, a singlefamily living in Tongi is improbable to visit relatives living in Savar and vice versa. In a shorter distance, single families living in Motijheel usually, if not bound to, will not visit another family living in Mirpur-1. The driving distance to the latter is around $12.3 \mathrm{~km}$ and is supposed to take 30 minutes. However, it takes more than 2-3 hours in rush hours and 1-2 hours at the weekend.

\subsection{Economic Impacts}

Sprawl incurs increased public expenditure. Both DSCC and DNCC, every year, expand public infrastructure to incorporate community service in the additional populations. Gazipur City Corporation, Savar City Corporation, and Nayaranganj City Corporation also expend to construct roads, lanes, parks, playgrounds, and green spaces. Because sprawl increases the distance between homes to businesses, services, and jobs, it raises the cost of providing infrastructure and public services. Of the total budgets of city corporations, around 55\% is sanctioned for developing housing and transport networks, as well as municipal services and waste management. A vast majority of tax money goes towards the endless building of roads and transport networks, with little left for valuable things like education, civic buildings, quality architecture, and public spaces. Even after that, with distant housing, people now spend more time than ever in the stressful traffic jam, which is around $25 \%$ of the working hour a day per commuter.

\subsection{Environmental Impacts}

Urban sprawl not only degrades environmental resources such as water quality, air quality but also limits or eliminates accessibility to natural resources such as agricultural lands, and water. (Adelmann, 1998) (Barnes, 2001) (Hasse \& Menz, 2001). In recent times, owing to sprawl, Dhaka has been facing drastic environmental consequences like the rise in temperature, heavy rains, and flooding. About $90 \%$ of the city's water supplies come from ground reserves, which are depleted by three meters a year. There is a supply-demand gap of 500m liters a day, according to a 2014 report, leading to chronic shortages and protests in the summer months. The continuous building of ever more roads and highways, along with sprawling low-density development, is consuming miles of the unique natural environment. It is alleged to be associated with loss of environmentally fragile lands, reduced local open spaces, increased air pollution, higher energy consumption, and decreased aesthetic appeal of the landscape. Within three decades, Bangladesh is expected to be at least $2^{\circ} \mathrm{C}$ hotter. By the next 30 years, the sea level could be 2 feet higher. Moreover, all development management input needs like water, gas, and electricity, including land-use, drainage, solid and liquid wastes, air, and adjoining suburbs, have turned out to become increasingly counteractive stress on the environment. Human-Environment Interface in Dhaka has become a matter of alarming concern for the urban planners due to uncoordinated urban development that severely impairs ecology.

\subsection{Policy for Sustainable Development}

The paper tried to explore potential planning policies for the sustainable development of Dhaka. Under this approach, understanding the critical trends in urbanization and root causes is a gateway to unfold challenges over the coming years, and it is crucial to the implementation of the 2030 Agenda for Sustainable Development, including Sustainable Development Goal 11 to make cities and human settlements inclusive, safe, and sustainable. Given the vulnerable situation in Dhaka, it seems to be very urgent to make policies to secure the future of the city. Figure 3 frames the overall design for a sustainable response for making cities livable and sustainable. The following section discusses the exploration of pathways to overcome the emerging risks and challenges of Dhaka. 
Figure 3. A framework for Sustainable Development in Megacity

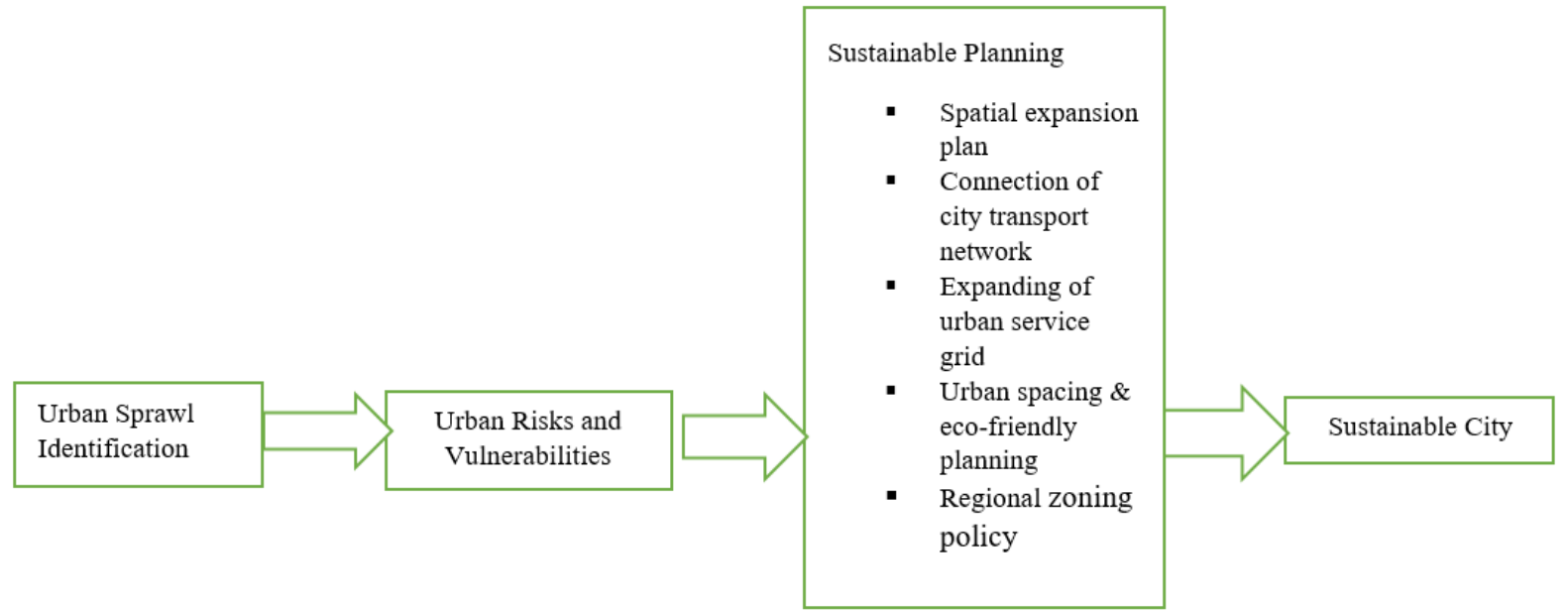

Source: Study findings 03 March 2019

\subsection{Efficient urban planning}

Urban planning systems in Dhaka follow a macro planning approach with political and bureaucratic influence. The administrative practice and service delivery approach are mostly manual and paper-based. This inefficient system tends to delay the processing of citizens' information requests and susceptible to potential corruption and wastage of resources. The challenge of dealing with an evergrowing influx of migrants requires urban administrators to use state-of-the-art planning technology through large-scale plans and comprehensive migrant rehabilitation policy. A good-governance framework also urges regular access to information about land, property, and housing. There is a growing demand for improving e-government to ensure efficient information management and effective urban service delivery systems (Doytsher $\&$ al, 2010).

\subsection{Water bodies and waste management}

The sustainability of the Dhaka city depends significantly on the water system and waste management. However, Dhaka lacks any such water management policy to avoid frequent flooding $\mathrm{n}$ the rains. The preservation of water bodies and natural waterways is vital to ensure an effective drainage system in Dhaka. The provision of separate sewage and stormwater drainage facilities is very urgent in this megacity to avoid seasonal flooding. The city also needs to revitalize the nearby rivers immediately by stopping the canal fills or waste deposits. Besides, an effective waste management system is considered to be very urgent in Dhaka. Unfortunately, Dhaka cannot collect $100 \%$ of the waste released by its residents daily. The combining of the informal waste recycling system under publicprivate participation would improve the overall waste management system in Dhaka.

\subsection{Housing policy}

The most critical policy implication is about the housing of the migrated an additional population. The booming housing sector plays the leading role in sprawling around the city. No formal control in the housing sector is pushing the price, causing middle- and low-income households to move out of suburban areas. As of now, the housing sector faces various challenges, such as lack of proper control in both formal and informal development processes. The public housing agency, RAJUK, should make a housing policy to provide more affordable housing, as the average housing prices are out of reach for most of the lower- and middle-income people in Dhaka. The government should provide sustainable guidelines for a neighborhood-based development model instead of a plotbased model or apartment housing. Improving housing conditions in slum areas is also critical as more than onethird of Dhaka's residents are living in these areas. Both city corporations have a budget for making houses in slums in terms of public service to accommodate poor migrants, but such initiatives are far less than required

\subsection{Infrastructural development for transport}

Mobility in a densely populated area is the priority that considers making an integrated transport network. The city has already started several initiatives, such as the development of an elevated expressway, flyovers, metro rail, and rapid transit systems, which would improve the mobility of people in Dhaka. To integrate the extended roads and lanes to the downtown transport network, Dhaka needs an integrated spatial transport network policy, which will save traffic hours and smooth mobility. Thus, constructing both link and ring roads and reviving the surrounding waterways can improve and connect the whole transportation network in Dhaka. All these initiatives should be undertaken as an integrated and good-governance framework as urban planning and land use. Dhaka thus requires 
immediate attention to upgrade its planning framework and services systems for sustainable growth, and for utilizing the total potential of the people, economy, and infrastructure.

\subsection{Public services for the migrant population}

This paper tried to emphasize on the utility service and housing policy for migrated people and linked it with the sustainability of the city. Every year some 700,000 people move to the cities. To date, around 7.0 million people have migrated to cities, mostly in Dhaka. The fast-paced urban migration creates a housing demand of 130,000 additional units each year. However, in the absence of adequate policies and sufficient budget, there is a significant deficit to build the additional housing units, and the deficit is projected to increase to 8.5 million units by 2021 . Another issue is the lack of water supply. There is a supply-demand gap of at least $500 \mathrm{~m}$ liters a day in Dhaka. City corporations do not have specific measures, plans, and policies to ensure additional housing, water supply, and medical services for the urban migrants. Under the urban development program with a routine budget, few housing units or infrastructure developed is far less than necessary. This gap is getting bigger and making city life unsustainable.

\subsection{Conclusion}

Dhaka continues to get urbanized, with more than half of its population living in urban places, ranging from rural towns to the megacity. In just another 15 years, Dhaka will be home to a population of over 30 million. Hence to accommodate such a vast population along with other associated services, urban planners must make state-of-theart urban development plan. This research paper has identified where the sprawl (informal urbanization) was taking place and what factors were causing it. Gazipur, Savar, Narayanganj, Rupganj and Bandar area spotted with sprawl in fringe areas using the land cover maps and built-up density to make cities sustainable. The Sustainable Development Goals acknowledge this growing concern and make provision for it in SDG 11: "Make cities and human settlements inclusive, safe, resilient and sustainable." In line with this goal, the future of Dhaka needs to be realized as a better mix of urbanized areas and agricultural spaces. The provision of urban and agricultural areas will require the zoning of agricultural lands and very rigidly preserving its status. Simultaneously, forests, hills, and water bodies and wetlands must be conserved strictly. Since Dhaka will have a much larger population in the future, the need for planning for urban-type high-density settlements will be of paramount importance.

The methods and techniques employed in this study may serve as guidelines for future applications across varied landscapes. Furthermore, the resulting land cover maps and spatial information generated from this study may assist planners, stakeholders, and academia with a scope detailed understanding of land cover change, urban growth patterns, and associated ecological risks in Dhaka's mega-urban region of Bangladesh, thus helping to make better planning decisions for a more sustainable urban future.

\section{References}

Adelmann, G. (1998). Reworking the landscape, Chicago style, In The Hastings Centre Report, 28(6), 6-11.

Alberti, R. J. (1991). Geographic Information Systems: Applications For The Study Of Real Estate. Appraisal Journal, 60(4):, 483-492.

Barnes, K. e. (2001). Sprawl development: its patterns, consequences, and measurement. Towson University, Towson, S., 1-24.

Baumgart, S., \& Kreibich, V. (2011). Informal Urbanization-Historical and Geographical Perspectives. The Disp Plan. Rev., 47, ., 12-23.

Black, J. T. (1996). The Economic of Sprawl. Urban Land. March 55:3, , pp. 52-53.

Burchell, R. W. (2005). Sprawl Costs: Economic Impacts of Unchecked Development. Island Press. USA.

Burchfield M., O. H. (2006). Causes of sprawl: A portrait from space, , ,. Quarterly Journal of Economics, 121 (2), 587-633.

Burgess, P., \& Thomas, B. (1998). : Public Policy and "Rural Sprawl": Lessons from Northeast Ohio," In The Urban Center, Levin College of Urban Affairs, Cleveland State University. In The Urban Center, Levin College of Urban Affairs, Cleveland State University.

Choe, K., \& Roberts, B. (2011). Competitive Cities in the 21st Century: Cluster-Based Local Economic Development Mandaluyan City; . Asian Development Bank: Manila, Philippines.

Corner, R., \& Dewan, A. (. (2014). Introduction. In Dhaka Megacity: Geospatial Perspectives on Urbanization, Environment, and Health; pp. 1-22.: Springer: New York, NY, USA.

Daniels, P. (2004). Urban challenges: The formal and informal economies in mega-cities. , . Cities, 501-511.

Degert, I., Parikh, P., \& Kabir, R. (2016). Sustainability assessment of a slum upgrading intervention in Bangladesh Cities 2016, . 56, 63-73. .

DMDP, R. (2007). Strategic Environment Assessment Report, retrieved from (http://documents.worldbank.org/curated/en/945651468003307657/Dhaka-metropolitan-development-planstrategic-environmental-assessment). Dhaka: RAJUK. 
Doytsher, Y., \& et al. (2010). Rapid Urbanization and Mega Cities: The Need for Spatial Information Management;,. A research study by FIG Commission; International Federation of Surveyors. FIG Commission 3: Copenhagen.

DSCC. (2012). DSCC (Dhaka South City Corporation). Dhaka: Dhaka South City Corporation: Dhaka Bangladesh,.

Grimm, N. e. (2008). Global change and the ecology of cities. Science, 319, pp. 756-760.

Hackenbroch, K., Hossain, S., Altrock, U., Schoon, S., \& Sterly, H. (2016). Informality, urban governance, and the state: Negotiations of space in Dhaka and the Pearl River Delta. . nt. Dev. Plan. Rev. 2016, , 229-253.

Haque, S., Onodera, S., \& Shimizu, Y. (n.d.). An overview of the effects of urbanization on the quantity and quality of groundwater in South Asian megacities.. 2013, Limnology, 2013, 14, 135-145.

Harder, A. (2013). Determining Program Priorities. WC105. Gainesville: University of Florida Institute of Food and Agricultural Sciences. Retrieved April 10, 2015, from https:// edis.ifas.ufl.edu/wc105.

Hasse, J., \& Menz, G. (2001). Land Resource Impact Indicators of Urban Sprawl, A. Applied Geography, 23(2-3), $159-175$

Jaeger. (2010). Suitability criteria for measures of urban sprawl, In Ecological Indicators,. 10, S., 397-406.

Kabir, A. (2013). The Urban Spatial Structure of Employment and Its Impacts on Transportation and Urban Development: A Case Study of Dhaka Megacity; University of New South Wales: Sydney, Australia, 2013.

Kusher, C. (2001). How is Sprawl Related to Landscape Change in Cities? r. Retrieved from (http://www.sprawlcity.org

L. Goering. (2016). The rising tide of climate migrants' spurs Dhaka to seek solutions. The article was accessed on 24 February 2019 from https://www.reuters.com/article/us-bangladesh-migrants-climatechange/risingtide-of-climate-migrants-spurs-dhaka-to-seek-so.

McPherson, P. (2015). Dhaka: the city where climate refugees are already a reality. The news was accessed on 23 March 2019 to https://www.theguardian.com/cities/2015/dec/01/dhaka-city-climate-refugees-reality.

Onodera, S. (2013). An overview of the effects of urbanization on the quantity and quality of groundwater in South Asian megacities.. Limnology, 2013, 14, 135-145.

Pelling, M., \& Blackburn, S. ( 2013). In Megacities and the Coast: Risk, Resilience, and Transformation; Executive Summary. Routledge: New York, NY, USA.

RAJUK. (2015). Dhaka Structure Plan 2016-2035; Rajdhani Unnayan Kartripakkha: Dhaka, Bangladesh, 2015. Dhaka: Rajdhani Unnayan Kartripakkha:.

Seto, K., G. B. (2012). Global forecasts of urban expansion to 2030 and direct impacts on biodiversity and carbon pools, Proceedings of the National Academy of Sciences of the United States of America 109.40,, (pp. pp. 16083-16088).

The World Cities. (2018). The World Cities in 2018, Data Booklet. DOI::https://doi.org/10.18356/c93f4dc6-en

UN, 2. (2018). 2018 Revision of the World Urbanization Prospects; UN. United Nations: New York, NY, USA. www.worldatlas.com. (2018). The World's Most Densely Populated Cities. Retrieved from Retrieved from https://www.worldatlas.com/articles/the-world-s-most-densely-populated-cities.html 